\title{
Challenges of BFIs in Cash Transfer Program to Earthquake Affected Victims: Lessons from Nepal's Earthquake 2015
}

\section{Tej Bahadur Karki}

Social Development Specialist, National Reconstruction Authority (NRA)

Email: drtej.karki@gmail.com

\section{Rita Lamsal}

Section Officer, NRA, Singhdurbar, Kathmandu, Nepal

Email: lamsalrita@gmail.com

\section{Namita Poudel Bhusal}

Banking Specialist, PhD Student, University of Hull, United Kingdom

Email: namitapoude124@gmail.com

\section{Corresponding Author}

Rita Lamsal

DOI: https://doi.org/10.3126/irjmmc.v2i3.40057

Received: August 21, 2021; Revised \& Accepted: September 15, 2021; Published: September 29, 2021

(C) Copyright: Lamsal (2021).

\section{ABSTRACT}

The government of Nepal successfully managed the post-earthquake housing reconstruction and rehabilitation endeavours in the aftermath of Nepal's earthquake 2015, where more than 800,000 Earthquake affected households were identified as beneficiaries and provided financial assistance to build their house. The purpose of this research is to explore the challenges faced by the Banks and Financial Institutions (BFIs) during the cash grant distribution procedures for the earthquake beneficiaries. This paper is prepared to explore the Government of Nepal's private housing reconstruction initiatives as an effort to cope with the post-earthquake reconstruction and rehabilitation works and the role of BFIs in disbursing of the government's conditional cash transfer program to the identified earthquake beneficiaries. The study had collected data from 16 BFIs where 53 respondents participated in the study. It is based on the qualitative design because structured interview was conducted to collect the data. The findings show that private housing reconstruction endeavours focusing on the cash transfer programs of the GoN were more effective, where $99 \%$ of the beneficiaries received the $1^{\text {st }}$ Tranche as of June 2021. Though, there were several challenges shared by the respondents during the grant transfer mechanism such as human resource management, lack of financial literacy and understanding of bank-related services, lack of adequate coordination among the concerned stakeholders, merger and acquisition of BFIs, beneficiaries' ownership/nominee transfer, cash management, mismatch of the beneficiaries name, and reconciliation and data verification. The study would be crucial to learn important lessons from Nepal's post-earthquake reconstruction for future disaster resilience activities.

Keywords: Access to Finance, Banks and Financial Institutions (BFIs), Cash transfer, earthquake beneficiaries, financial assistance, financial literacy, post-earthquake, reconstruction. 


\section{INTRODUCTION}

Nepal earthquake of 2015, also known as "Gorkha Earthquake" struck on the $25^{\text {th }}$ April and the subsequent aftershocks triggered severe devastation and colossal loss of lives and property. The epicentre was in Gorkha district near Barpak village (about $80 \mathrm{~km}$ northwest of Kathmandu, the capital city of Nepal) consequently severe jolt was felt in Kathmandu as well as other regions. According to the Post-Disaster Need Assessment (NPCPDNA,2015), the "Gorkha Earthquake 2015" disaster caused the fatalities of 8,790 people and more than 22,300 injured. Apart from the colossal loss of lives and destruction of 498,852 private houses 2,656 government buildings, almost 256,697 private houses and 3,622 government buildings were partially damaged, while 19,000 school classrooms were destroyed and 11,000 were fully damaged (NPC-PDNA, 2015).

As per the Post Disaster Reconstruction Framework (PDRF), the total economic value of the disaster effects (damages and losses) caused by the earthquake was estimated NPR 706 billion (the US\$7billion), which was almost one-third of Nepal's annual GDP (NRA-PDRF, 2016). For its recovery, the financial need was estimated at NPR 669 billion or US\$6. 7 billion (NPC-PDNA, 2015). As per the Post Disaster Need Assessment (PDNA, 2015) the largest single need was identified for housing and human settlements. About 755,000 houses in Nepal were found destroyed or significantly damaged accounting forUS\$3.27 billion or almost half of the total reconstruction needs (NPC-PDNA,2015). Due to the earthquake, 32 districts (out of the total 77) were affected, of which 14 districts(Okhaldhunga, Dolakha, Ramechhap, Sindhupalchok, Kavrepalanchok, Sindhuli,Bhaktapur, Gorkha, Kathmandu, Lalitpur, Rasuwa, Nuwakot, Dhading, Makwanpur)were declared as "severely affected" and the other 18 neighbouring districts(Tanahu, Lamjung, Sankhuwasabha, Bhojpur, Dhankuta, Khotang, Solukhumbu,Chitwan, Kaski, Parbat, Baglung, Myagdi, Syangja, Palpa, Gulmi, Arghakhachi, East-Nawalparasi, West-Nawalparasi)were listed as "partially affected".

The Government of Nepal (GoN) came up with various policies and programs to concordat with the merciless disaster. Consequently, the GoN established National Reconstruction Authority (NRA) as an independent agency on the 25th December 2015 for five years and had extended for one year to manage a multi-sector recovery and reconstruction program. The goals and objectives of the NRA are to support in the reconstructing and retrofitting of the private houses, reconstruction of public schools, reconstruction of archaeological and historical heritage sites, reconstruction/retrofitting of health institution buildings, reconstruction/retrofitting of government buildings, and rehabilitating the security sector buildings. NRA has been involved to rebuild and rehabilitate all Earthquake (EQ) affected structures however, this article concentrates only on the BFIs role and challenges in private housing reconstruction activities of the earthquake victims. 


\subsection{Private Housing Grant Payment Mechanism}

Private Housing Grant payment mechanism for the earthquake beneficiaries is one of the core functions of NRA to route the cash grant through BFIs to support in their owner driven private housing reconstruction initiatives. As per the "Grant Disbursement Procedures for Private Houses" 2072 (2015), financial assistance is provided in the form of a cash grant for the reconstruction and or retrofitting to individual beneficiaries in multi-tranches. The Private Housing Grant payment mechanism is implemented in coordination with Nepal Rashtra Bank and commercial banks to disburse the funds (NRA-PDRF, 2016). Therefore, it is mandatory for all the programme households i.e. earthquake beneficiaries to open bank accounts to receive conditional cash transfer in multiple trances. A uniform subsidy of a total cash grants of NPR 300,000 (about US\$ 3,000) in three tranches is provided for housing reconstruction and NPR 100,000 in two tranches for retrofitting of houses for the eligible beneficiaries which are divided into three different categories.

- Non-beneficiary: Damage grade level $1 \& 2$ minor (structurally safe to live in): not eligible for a housing grant.

- Retrofitting-beneficiary: Damage grade level 2 major \& 3 minor (retrofitting is needed to live in): eligible for NPR 100,000 housing grant.

- Reconstruction-beneficiary: Damage grade level 3 major, $4 \& 5$ (mandatory to reconstruct): eligible for NPR 300,000 housing grants.

As per the NRA data as of $30^{\text {th }}$ June 2021, the total numbers of Private Housing beneficiaries who signed an agreement to receive cash assistance are 818,624 out of which 816,670 beneficiaries $(99.9 \%)$ had received $1^{\text {st }}$ Tranche of grant, 727,328 (88.9\%) beneficiaries received $2^{\text {nd }}$ Tranche and 665,233 (81.3\%) beneficiaries received $3^{\text {rd }}$ Tranche and out of total 53,958 retrofitting beneficiaries, 45,814 (84.9\%) beneficiaries signed agreement and 45,781(84.8\%) retrofitting beneficiaries received $1^{\text {st }}$ Tranche (NRA, 2021).

\subsection{Access to Financial Services for the Earthquake Beneficiaries}

The role of BFIs has been evinced substantial in the time of the disaster and emergencies in providing the access to the financial services to the disaster affected victims to route the financial assistances (Arshad and Athar, 2013). BFIs in Nepal have played major role in transferring cash grants to the eligible EQ victims through the banking channel and mitigating various financial and fiduciary risks associated with the grant management program (Poudel, Aryal, \& Lamsal, 2020). To support GoN's envisioned goal and objectives of providing inclusive finance endeavours, NRA entered into a Memorandum of Understanding (MoU) with the Standard Operating Procedures with the various BFIs and respective Bankers Associations to disburse cash grants directly in the bank account of the eligible beneficiaries of 32 earthquake affected districts. Private Housing conditional cash grants are directly deposited into the pre-allocated individual beneficiary bank accounts after the necessary verification in the multi-tranche-based systems linked to the owner-driver construction progress.

NRA's initiatives in Private Housing Reconstruction in particular of disbursing the cash grant payment through the Banking channel has established to have supported in enriching and enhancing the access to the financial services to a large number of earthquake 
beneficiaries residing in the rural and remote areas with limited or no formal access to financial services (Poudel, Aryal, \& Lamsal, 2020). The momentum of transferring funds directly to the bank accounts of the earthquake beneficiaries provided the BFIs immense opportunities to tap the unbanked segment of the population in the formal banking channel. The previous research conducted by Poudel, Aryal, \& Lamsal, (2020). It has also highlighted NRA's private housing reconstruction initiatives led to the significant increase in the Bank's branch network with addition of 1,573 branches in 32 earthquake affected districts. NRA's initiatives has instituted to have contributed in enhancing access to financial services as per the GoN and Central Bank's envisioned strategies to expand financial inclusion in Nepal and in particular to the deprived rural population.

The Post-disaster Grant Payment Mechanism as implemented during the Pakistan earthquake 2005 established under the Rural Housing Reconstruction Program was further developed and used in another natural disaster of 2010/2011 floods. The beneficiaries received compensation grants through a centralized system of debit/ATM cards, linked with the national level citizen identification database (Arshad and Athar, 2013). The implementation of Grant Payment Mechanism in the "Pakistan Earthquake 2005" was evinced to have provided crucial access to financial services to the unbanked segments initiated through the direct bank transfer in particular the rural dispersed and isolated settlement with low level of financial literacy or no formal access to financial services. Due to the direct transfer of cash grants in the bank account, over 611,000 accounts (including 300,000 new ones) were successfully integrated for the direct transfers of grants with the invaluable support from the commercial banks to tie up in the National database and to link the access to the financial services. The method of associating the financial assistance with the grievance handling mechanisms is also found to be a crucial factor to trace, monitor, expedite the funds after the necessary eligibility assessments in post-disaster context (Arshad \& Athar, 2013).

The NRA's private housing reconstruction initiatives have been found to have contributed to enhancing access to financial services (Poudel, Aryal, \& Lamsal, 2020).Approximately 820,000 (as of June 2021) eligible identified beneficiaries are on track to receive formal access to the financial services, which has greatly contributed to the substantial growth of the new customers to the BFIs, creating awareness of formal banking practices, access to financial services supporting towards the government's vision of financial inclusion (NRB, 2021).

Therefore, it is crucial to research to examine the effectiveness of cash transfer programs and the role of BFIs in disbursing conditional cash transfers to the earthquake beneficiaries through the banking channels in Nepal. This research is aimed at investigating the challenges encountered by BFIs during cash disbursement procedures in Nepal after the earthquake. In the first stage, the study examined the GoN approach to identify (EQ) housing beneficiaries and cash transfer strategies that were implemented by GoN and then how the BFIs were engaged and mobilized to distribute grants to the EQ beneficiaries. Then in the second stage primary data were collected from the directly involved staff from the BFIs. At the third stage, the policy recommendation was provided for better preparedness in future. 


\subsection{Coordination between stakeholders in Grant Distribution}

The National Reconstruction Authority prioritized on channelling the grant disbursements through Banks \& Financial Institutions in adopting the efficient and transparent mechanism, mitigating financial risks associated with in the Grant Management process. As per the "Grant Disbursement Procedures for Private houses destroyed by the Earthquakes, 2072 (2015), a multi-tranche grant payment mechanism was developed that was closely tied to beneficiary eligibility with the cash transfer in the bank account to maintain transparency, and further technical inspection and certification regime was followed to approve to release subsequent tranches. Numbers of institutions are involved on this process for instance, DLPIU-GMaLI, Local Government (LG), District Treasury Control Office (DTCO) and BFIs. The each institution has been assigned with the specific roles and responsibilities to maintain effectiveness and transparency in flow of housing grant through central level to beneficiary bank account as per the NRA Grant Disbursement Procedures for Private Houses 2015, and smooth coordination between those institutions is utmost necessary.

Table 1: Responsible Agencies and Their Role in Grant Distribution Process

\begin{tabular}{|c|c|c|c|}
\hline SN & Activities & Responsible Agency & Details Description \\
\hline 1 & $\begin{array}{l}\text { Beneficiary } \\
\text { Identification }\end{array}$ & $\begin{array}{l}\text { Central Bureau of } \\
\text { Statistics (CBS), } \\
\text { Ministry of Federal } \\
\text { Affairs and Local } \\
\text { Development } \\
\text { (MoFALD), NRA }\end{array}$ & $\begin{array}{l}\text { The beneficiaries are identified by trained } \\
\text { surveyors in the districts through CBS } \\
\text { using the approved Survey Forms of } \\
\text { earthquake housing reconstruction detail } \\
\text { collection guideline. }\end{array}$ \\
\hline 2 & $\begin{array}{l}\text { Signing of } \\
\text { Participation } \\
\text { Agreement(PA) } \\
\text { documents }\end{array}$ & $\begin{array}{l}\text { Beneficiary \& Local } \\
\text { Level/Ward Unit }\end{array}$ & $\begin{array}{l}\text { In the leadership of DLPIU-GMaLI, the } \\
\text { process of signing of the Participation } \\
\text { agreement with the beneficiary at the local } \\
\text { levels/ward unit is conducted. }\end{array}$ \\
\hline 3 & Bank Account & $\begin{array}{l}\text { Beneficiary and Bank } \\
\text { Mapping }\end{array}$ & $\begin{array}{l}\text { Opening of the bank account after the PA } \\
\text { agreement as per the eligibility criteria and } \\
\text { accordingly } 1^{\text {st }} \text { Tranche is released in the } \\
\text { allocated bank account of the beneficiary. }\end{array}$ \\
\hline 4 & $\begin{array}{l}\text { First Tranche } \\
\text { disbursement } \\
\text { process }\end{array}$ & Local Level & $\begin{array}{l}\text { Upon the recommendation of the local } \\
\text { level/Ward after the completion of the PA } \\
\text { agreement, DLPIU-GMaLI approves the } 1^{\text {st }} \\
\text { Tranche disbursement through District } \\
\text { Treasury Control Office (DTCO) to the } \\
\text { beneficiary's allocated bank account. }\end{array}$ \\
\hline
\end{tabular}


International Research Journal of MMC (IRJMMC)

\begin{tabular}{|c|c|c|c|}
\hline 5 & $\begin{array}{l}\text { Technical } \\
\text { Inspection -1 }\end{array}$ & $\begin{array}{l}\text { Technical Person in } \\
\text { DLPIU - Building }\end{array}$ & $\begin{array}{l}\text { Inspection of completion of foundation } \\
\text { and plinth level construction as per the } \\
\text { seismic resilience and verification of } \\
\text { standard using inspection guideline forms }\end{array}$ \\
\hline 6 & Second Instalment & Local Level/Ward Unit & $\begin{array}{l}\text { After the necessary eligibility verification } \\
\& \text { upon the recommendation of local level } \\
\text { by DLPIU-GMaLI.The second instalment is } \\
\text { provided after the first inspection of the } \\
\text { construction above the plinth level in the } \\
\text { beneficiary's bank account. }\end{array}$ \\
\hline 7 & $\begin{array}{l}\text { Technical } \\
\text { Inspection -2 }\end{array}$ & $\begin{array}{l}\text { Technical Person in } \\
\text { DLPIU-Building }\end{array}$ & $\begin{array}{l}\text { Regular inspection of seismic resilience } \\
\text { construction of structure with Roof-Band, } \\
\text { Sill Band, Stich Band Lintel Band in } \\
\text { appropriate level above the plinth level } \\
\text { plinth level work and verification of } \\
\text { standard guideline using inspection form }\end{array}$ \\
\hline 8 & Third Instalment & Local Level/Ward Unit & $\begin{array}{l}\text { The Third instalment of NPR } 100,000 \text { is } \\
\text { transferred to the beneficiary's bank } \\
\text { account after the second inspection of } \\
\text { roofing works and as per the } \\
\text { recommendation of the local level by } \\
\text { DLPIU-GMaLI. }\end{array}$ \\
\hline 9 & Final Inspection & $\begin{array}{l}\text { Technical Person in } \\
\text { DLPIU-Building }\end{array}$ & $\begin{array}{l}\text { Overall completion all stages of inspections } \\
\text { as per the seismic resilient housing } \\
\text { structure guideline that is safe and secure. }\end{array}$ \\
\hline 10 & $\begin{array}{l}\text { House Completion } \\
\text { Certification }\end{array}$ & Local Level/Ward Unit & $\begin{array}{l}\text { The beneficiary will be provided with the } \\
\text { house completion certificate after meeting } \\
\text { all the compliance as per the guideline set } \\
\text { by GoN. }\end{array}$ \\
\hline
\end{tabular}

(Source: Grant Disbursement Procedures 2072)

For the reconstruction beneficiary, the first tranche of NPR 50,000 grant amount is received by the beneficiary after the agreement with the ward unit Village Development Committee/Municipality (current rural municipality/urban municipality) to build a safe house (earthquake resilient house). After the necessary verification by technicians designated to concerned ward unit and Rural /Urban Municipality of completion of foundation level and up to the plinth construction, they get the remainder grant amount in Tranches of NPR 150,000 and by the time of roof construction they get the remaining amount NPR 100,000. The third instalment is conditional on installation of toilets in houses; installation of solar energy panels is also encouraged. For the retrofitting beneficiary, second instalment NPR 50,000 is provided after the completion of full maintenance. 
The financial assistance is disbursed to the individual beneficiary through banks by the DTCO, after the appropriate recommendations and approval from concerned DLPIU-GMaLI, the funds are deposited in instalments direct in the bank accounts of the identified earthquake beneficiary.

\subsection{Cash Disbursement Theory}

Disbursement of funds may be defined as a release of funding for the continued project operations from one entity, in this case, the donor, to the appointed borrower's beneficiary PIU. The money is generally loaned, granted or combined. A donor undertakes to distribute cash following acceptance of the loan if PIU requests a first payout, rebuff or direct payment. The donor will evaluate this and then approve the release of a certain amount of funding (Keng'ara, 2014). As Reider (2008), cash disbursement systems can be managed in many ways to control cash outflows and save money on interest-taking accounts for as long as possible. An analysis of these three disbursement theories is shown:

\subsubsection{Prefunding System}

A prefunding disbursement system is the safest and the simplest method of cash disbursement. As per this system, the amount of money required to cover all checks written is in the disbursement bank account at the time the checks are written. As the checks clear, the money is already there to cover them, and there are no chances of bounced checks. However, this system removes money from interest-bearing chances before their actually being need to cover the written checks. The safety in it comes with a price (Reider, 2008).

\subsubsection{Estimated Funding}

Another cash disbursement system that is more economical and efficient, but riskier, is estimated funding, where checks are written at once and the funds required to cover those checks are deposited in the disbursement bank account based on estimation of when the checks will be cleared. This system is deemed effective in situations where historical patterns of clearance can be studied and predicted with reasonable accuracy such as in dividend accounts or payroll accounts. The danger, of course, is inaccurate prediction, which can cause the possibility of bounced checks. This approach should be selected only after thorough analysis and careful consideration (Reider, 2008).

\subsubsection{Controlled Disbursement Funding}

The payment management system called controlled disbursement funding management works in partnership with the company's banking institution. Here the bank informs the company daily of the number of checks submitted for payment. The company then arranges for the transfer of sufficient funds to the paid account to cover those checks. The company's use of float has been increased, the company's money remains in the interestbearing form for a longer period of time, and it is possible that the bounced checks or dishonoured checks will be completely removed. The company's bank may demand money for this service, which may deduct part of the savings, and the company may need to protect itself from potential over-draft or other borrowing possibility to cover potential shortfalls (Reider, 2008).

Use of the disbursement float is not illegal, but cash must be readily available when they are presented to the bank for payment for covering the checks. While deciding on the 
method of how company's cash disbursement system, the review team needs to keep in mind the company's goals and policies regarding disbursements - that is, using the float to benefit the company and to make payments payable when it is presented, not when it is written (Reider, 2008).

\subsection{Agency Theory}

The cash disbursement system is also defined by the agency theory. This refers to an interaction between the agent and the principle, in which the agent entrusts him with the ability to carry out specific duties on behalf of himself. As Odedukun (2003) has shown, in this situation the donor is the principal, whereas the receiving country is the agency. The donor specifies the quantity of money that are to be distributed and channels the borrower to decide on expenditure patterns, which eventually lead to outcomes such as economic growth, the construction of infrastructure, the access to education and health care.

\section{OBJECTIVES OF THE RESEARCH}

The main aim of the study is to explore the challenges faced by BFIs in disaster setting in Nepal after the earthquake of 2015. The study intends to examine the Private Housing reconstruction endeavours focusing on the cash transfer programs of the GoN through BFIs. The specific objectives of this study are to:

1. Identify the challenges faced by BFIs during the grant disbursement process and lessons to be learnt for the future, and

2. Provide policy level recommendations for the appropriate cash transfer mechanism for better preparedness in future.

\section{METHODOLOGY}

The study adopted the qualitative design to explore the experiences of BFIs in disaster response settings. A judgemental sampling technique was used to select the respondents of BFIs to collect primary data. The directly involved staff of the BFIs in the grant distribution process, such as managers, operation-in-charge and customer service assistants were selected as a sample. Almost 16 BFIs participated in the survey and 53 respondents filled up the questionnaire survey forms collected in January 2021, through an online and questionnaire survey.

Out of a total16 participating BFIs, there were 11 Commercial Banks, four Development Banks, one Financial Institution. The participants in this research -study filled the survey forms and the respondents comprised of branch managers, IT officers, operation in-charge, assistants and other officers representing respective departments of the Bank's Central Head offices and branches who were directly involved in the grant distribution process. Based on the qualitative data received from respondents, answers were categorized in different headings to identify the challenges they faced during the grant distribution process.

Review of various disaster management strategies, guidelines, policies and acts was made. Besides, the operational modalities in emergency response and the coordination mechanism were also assessed. 


\section{FINDINGS OF THE STUDY}

The study has presented the findings collected by using open-ended questions. The study focused on challenges faced by BFIs during the grant distribution process to the earthquake beneficiaries. In total 53 respondents participated in this research study. The details of the respondents are as listed below:

Table 2: Research Participants

\begin{tabular}{lll}
\hline S.N & Position & No. of People \\
1 & Branch Manager & 15 \\
2 & Relationship Manager & 1 \\
3 & Officer & 6 \\
4 & Operation In-charge & 9 \\
5 & Assistant (Junior/senior) & 22 \\
& Total & $\mathbf{5 3}$ \\
\hline
\end{tabular}

As established during the research study, most of the respondents stated that "the grant distribution process was effective and it was transparent, scientific, quite systematic, and not much complicated so far". However, there were some challenges faced by the BFIs during the grant distribution process. The challenges highlighted by the BFIs staff were as followings:

1. Human Resource Management in Banks

2. Lack of financial literacy among the beneficiaries

3. Inadequate Coordination among stakeholders

4. Merger and Acquisition of BFIs

5. The problem in Beneficiaries Ownership transfer

6. Challenges of Cash Management

7. Mismatch of the Beneficiaries personal information

8. Reconciliation and data verification

\subsection{Human Resource Management in Banks}

In total there are approximately 820,000 identified earthquake beneficiaries who are eligible to receive the cash grants and out of which 818,624 beneficiaries have signed an agreement to reconstruct their houses. And out of the total signed beneficiaries 816,670 beneficiaries $\left(99.9 \%\right.$ ) have received $1^{\text {st }}$ tranche of grant as of $30^{\text {th }}$ June 2021(NRA, 2021). During the grant disbursement procedure for the targeted beneficiaries, long queues in front of the banks were observed with a huge crowd in the banks. The respondents stated, "Our Banks added several new temporary staffs to expedite the grant disbursement process to the earthquake beneficiaries but still it was difficult for us to manage the big influx of new earthquake beneficiaries at the same time in providing the services". In addition, the respondents stated 'the issues of the high staff turnover in BFIs and lack of knowledge and skills transfer regarding the cash grant payment process and provisions among staff were perceived to be a challenge for the staff to deliver prompt services'.

To manage the appropriate bank allocation of the earthquake beneficiaries, the NRA completed the pre-allocation of beneficiaries through bank mapping process as per their 
location to the nearest BFIs, but in some areas, the assigned bank was far from their residence so they could not withdraw the cash grant from the nearest bank. It had also created difficulties for the beneficiaries and the bank to make payment in time.

Therefore, to resolve such issues some respondents had suggested mobilizing microfinancing institutions which could be more effective because micro-financing institutions have their direct reach to the grass root people and most of the branches of micro-financing institutions are spread in the remote areas of Nepal.

\subsection{Lack of Financial Literacy among the beneficiaries}

The study found the next challenge based on the response that, "lack of financial literacy, unawareness about the bank related procedures among the beneficiaries". Most of the beneficiaries are from remote areas and are illiterate, old and poor so it was difficult for us (bank's staff) to communicate with them".

The respondents shared that "the beneficiaries had very little knowledge about the banking procedure for receiving grant assistance provided by the Government of Nepal. Some beneficiaries had incomplete and misinformation about the banking process of grant distribution which created conflict between the beneficiaries and the banks. There was no adequate dissemination to educate the beneficiaries about the process of grant distribution. Illiteracy of the beneficiaries is another challenge. Due to financial literacy and the lack of understanding of the banking-related process, it was difficult to complete the banking procedure and documentation by the beneficiaries. It also created difficulties to fill up the account opening form details and to update KYC (Know your customer) form by the beneficiaries which are compulsory for all to operate the bank accounts".

\subsection{Inadequate coordination among the stakeholders}

The respondents also shared that there is a need for coordination between NRA and its Central Level Project Implementation Units(CLPIUs) and District Level Project Implementation Units (DLPIUs) of NRA, District treasury control office (DTCO), local municipalities and BFIs during the grant distribution process because of their involvement in the policy formulation, implementation, beneficiaries' identification and recommendation to finally route the transfer of the funds into the beneficiaries' account. As per the institutional provision, the NRA-DLPIUs provide the name list of beneficiaries to DTCO which provides funds through the concerned banks and subsequently beneficiaries account is opened and BFIs credit the funds in their respective account. There is also a provision to support the vulnerable beneficiaries to receive the conditional cash grant, if the beneficiary himself/herself could not be present physically in the bank to withdraw the money, the local government (respective Municipality office) could recommend and provide nominee detail with other necessary documents and verifications to provide the amount to the nominee.

Some respondents shared that "Sometimes our bank could not provide cash to the beneficiaries or nominees when all documents were not available. In such circumstances, there is a requirement of immediate coordination and communication among the concerned stakeholders to resolve the problem of beneficiaries. But it was not easy to resolve the grant distribution-related problems immediately due to lack of immediate contact with the concerned authority and prompt action on raised concerns". Therefore, the respondents strongly recommended the concerned institutions and officials maintain the active 
coordination and communication mechanism to expedite the grant disbursement process to the disaster affected victims.

\subsection{Merger and Acquisition of BFIs}

The term "merger and acquisition" (M\&A) refers to the purchasing and sellingacquiring and disposing of - of both private and public businesses. A takeover is another term for the acquisition of a publicly listed firm (Creighton, 2015). In a merger and acquisition, the acquired firm voluntarily transfers its assets and liabilities to the acquiring business. Many businesses choose to integration with another organization to protect their operations against failure. A winning approach is to move forward with M\&A with successful similar businesses (Ansari \& Mustafa, 2018).

During the field visit, respondents shared "that mergers and acquisitions of BFIs had created the problem to keep the correct record of beneficiaries. They said that many BFIs merged and as a result, there were issues of appropriate record transfer and record maintenance concerns due to the software change or transfer of data among merging banks and the reshuffle of staff also impacted the service delivery. Therefore, it was difficult to extract exact information of beneficiaries as per the initial bank allocations to update and maintain the records. After the merger, banks were unable to find the pending cash grant payment data of previous banks prior merger, which was not traceable in the system due to the software system merger, subsequently creating reconciliation process and data management issues".

To support GoN's envisioned goal and objectives of providing inclusive finance assistance, NRA entered into a Memorandum of Understanding (MoU) with the Standard Operating Procedures with the 77 various Banks \& Financial Institutions \& respective Bankers Associations covering 32 earthquake-affected districts to disburse cash grants directly in the bank account of the eligible beneficiaries but after the Merger \& Acquisition among BFIs as of September 2020 only 41 BFIs were found to be active out of initial 77 service providers to route the cash grants (Poudel, Aryal, \& Lamsal, 2020).

\subsection{The problem in Beneficiaries Ownership transfer}

The respondents stated "While the main beneficiary is out of the country or severely suffered from immobility diseases, as a nominee their close relatives are recommended for necessary verifications from the concerned local levels to receive the conditional cash grants on behalf of the earthquake beneficiary from the bank for respective three tranches.

Sometimes, nominees are changed in second or third tranches due to various reasons i.e. foreign employment, deceased cases etc. In such cases, there is more paperwork needed, for instance, nomination letter from the actual beneficiaries, and recommendation letter from the concerned ward unit/municipality, DLPIUs and proof of relationship. As a result, causing further delay in the cash grant distribution process in verifying the relevant documentation".

Operation In-charge, one of the respondents of the leading commercial bank raised a particular issue regarding a case of a beneficiary in a prison. She added that "NRA has clear provisions regarding payment to related persons of either deceased or people who are outside the country. However, it has no clear provisions and only vague guidelines to make payment 
easier to related persons in case of people who are unwell or are not immediately available to collect the first installment (for example in case of a beneficiary who is in prison)".

Also in some cases, "if the beneficiary is deceased after receiving the first tranche, then the bank faces difficulties to provide the cash grants to their legal heirs from the deceased account. Sometimes the recommendation of the Local Government does not provide clear guidelines to release the payment. Respondents said that they had to face such issues and challenges to release and authorize such fund transfers. Beneficiaries were observed not to have clear guidelines and knowledge about such an official process nor could arrange the proper documentation to claim the funds legally" to expedite the owner-driven construction program.

Respondents also reported another issue such as "deceits in stating the nominee of the earthquake relief victims. In many cases, they put one nominee in bank account opening form or none at all and put another nominee who might or might not be their closest relatives. As a result, there is confusion as to which nominee can claim the amount". Also, since banks follow the nominee who was initially named in the initial account opening form. On the other hand, bankers suggested cutting off the provision of transferring ownership which creates duplication.

\subsection{Challenges of Cash Management}

"During the peak time of the government's cash grant disbursements to the earthquake beneficiaries, some banks located in the remote villages faced regular cash shortages. Every day, a high number of beneficiaries visited the banks to collect the cash grants". The government of Nepal provides NPR 300,000/ to each beneficiary and it has set the deadline of each tranche by which the earthquake beneficiary should obtain the conditional cash grant funds after necessary verification, inspection and recommendations by the certified officials of the owner-driver construction progress. Accordingly, the concerned beneficiaries queue in the bank to withdraw the funds as soon as it is credited into the bank account. But "due to the higher number of withdrawals of cash transactions in a remote area, many times banks faced a shortage of cash. It was difficult for the banks to manage cash in remote areas from another commercial bank or Nepal Rastra Bank in a short time due to the long-distance and poor condition of rural roads". Hence, beneficiaries were compelled to wait for more days to get cash withdrawals from the bank. Therefore, these logistic issues were also witnessed as one of the causes of delay in expediting the conditional cash transfer programs to the earthquake beneficiaries in private housing reconstruction activities.

\subsection{Mismatch of the beneficiaries personal information}

"Mismatch of the beneficiaries' names in the agreement paper and citizenship created the problem in verifying the documentations to follow the full banking process in the opening of the accounts. NRA provides the name list of actual beneficiaries to concerned ward units to arrange for the Personal Agreement (PA) documentations including the unique number called $P A$ number to tag and identify each beneficiary. If the information in the PA documents does not match with the provided identification documentation of the earthquake beneficiary, then it causes further delays and concerns to validate the information from the official escalations before crediting the funds". 
For example, if the name in the contract document does not match with the one in their citizenship document, then the concerned beneficiary is required to provide additional documentation from the concerned Rural Municipality and Municipality to make necessary corrections to validate the same. All these mandatory check provisions through the several official channels and BFIs sources are found to have mitigated various financial and fiduciary risks associated with the grant management process.

\subsection{Reconciliation and data verification}

Presently, NRA is in the exit phase and the completion stage of mandated five plus one-year tenure (2015 to Dec. 2021). Successively, at this stage, NRA and Banks are working collaboratively towards the reconciliation and data verification procedures for the robust data and record management process of all the earthquake beneficiaries who have obtained the respective tranches as per the Government of Nepal's financial assistance program for the owner-driven private housing reconstruction efforts. The GoN needs to check and verify whether all the earthquake beneficiaries' bank accounts have been credited or not. In this case, the grant amount withdrawal from the GoN treasury has to be credited to the concerned beneficiaries' accounts.

In this context, the respondent stated that "it should be easy to verify the records but due to the weak data management and manual database rather than software-based, reconciliation has been a huge challenge". Banks also started encountering several issues and discrepancies to verify all the data including (Beneficiaries name and amount) which they received from the GoN but were unable to match the equal amount received from GoN and credited amount in the beneficiaries' bank account. For instance, unidentified beneficiaries, unavailable beneficiaries who did not come to the bank to open the bank account or to claim the funds, the number of such beneficiaries were on hold with BFIs or returned through the DTCO but could not be updated in the system properly to reconcile causing further discrepancies of inflow and outflow of fund transfer data.

Several bank respondents have also raised "the issues of inaccessibility of data access, management-related issues, communication gaps through email and software system issues due to the branch located in a remote region with limited access to the internet facilities or frequent power cut hampering in service delivery and data reporting mechanisms. Some of the respondents also reported having provided ATM smart card to the beneficiaries rather than paper-based documents i.e., checks for the fund's withdrawals".

\section{DISCUSSION}

The NRA's Private Housing Grant Payment Mechanism has been found to have played a vital role in contributing towards the vision and mission of the GoN and NRB in providing inclusive finance to the earthquake beneficiaries in rural and remote areas. This case study exemplifies that a higher number of populations have acquired access to financial services from BFIs through the NRA's private housing reconstruction program. However, it is yet to examine the benefits of obtaining further financial products and services from BFIs after opening the accounts with the respective banks, although there is the nominal trend of saving money and using the bank account often by the earthquake beneficiaries as per the previous study conducted by Poudel, Aryal, \& Lamsal(2020). 
Respondents have highlighted several operational as well as policy-level issues during this research study. It demonstrated that in the emergency and crises the role of the government and private sectors collaborative efforts plays a crucial role to better support the disaster impacted victims to expedite the response and recovery process. Nepal's Gorkha Earthquake2015 positioned the country not only to tackle the grave grand challenges but also provided great opportunities to 'build back better'.

Although the earthquake caused colossal devastation and destroyed lives and properties, on the other hand, the opportunities to rise stronger than before through rebuilding earthquake-resilient owner-driven private houses reconstruction using new technology with GoN supported financial assistance -cash grants as well as technical skills. Similarly, BFIs also got great opportunity to bring in over 820,000 individual identified unbanked earthquake beneficiaries on board as the new customers into the formal banking process. The post-disaster Grant Payment Mechanism initiated by NRA to route the cash grant for the EQ beneficiaries in a multi tranche-based system has been one of the breakthroughs and key achievements in enhancing financial inclusion. Through transferring the cash grants to the large number of beneficiaries at the same time with a robust and transparent mechanism through the Banks achieving the GoN target in transferring in digital Nepal and also mitigating various financial and fiduciary risks. However, the cash grant distribution process for all the identified 820,000 individual earthquake beneficiaries was a huge task that was never seen before, existing BFIs faced immense pressure to provide access to financial services to a large number of beneficiaries at the same time. It was impossible to manage such an influx of new customers of this magnitude of the piloted project to open a new account for the earthquake beneficiaries at one go. Therefore, the BFIs managed several ways to simplify the process through the extension counters facilities with addition of additional staff, providing service in weekends and out of business hours, mobile banking services, Branchless Banking services (BLB)in absence of physical branch etc. to support in the one of the biggest private housing grant disbursement programs of the GoN to the disaster affected victims.

Even though, there were several challenges BFIs encountered in the biggest grant disbursement programs to the large number of disasters affected victims at the one time, several new collaborative alliances were formed such as multi-agency, inter-agency and interorganizational collaborations. The wider sector collaborations in post disaster context resulted in development of new Acts and regulations, partnerships, process, new technological innovations and key learning as a takeaway to be better prepared of the future disasters. The experience of rebuilding the nation back from the rubble has been incredible in such a short span of time through the collaborative endeavors among various stakeholders, out of which the role of BFIs has been found integral in disbursement of financial assistance to over 820,000 earthquake beneficiaries. Therefore, in such disaster settings, it is recommended to provide extra incentives or financial rewards to the front-line service providers such as BFIs staff or the related concerned officials in the future to motivate and retain them to work above and beyond as demonstrated in providing vital access to financial services in post-earthquake reconstruction and rehabilitation efforts. 
Hence, there should be good coordination and communication process among the involved stakeholders in synchronizing the Government grant distribution procedures to implement the developed guidelines and decisions in efficient manner. Similarly, to manage the data and reconciliation process, it would be the best strategy to prepare the robust data management system for tracking the process which can provide better ways to prompt support to the victims in future disasters as well as to track and reconcile the data discrepancies to mitigate financial and fiduciary risks.

\section{CONCLUSION AND RECOMMENDATIONS}

NRA's initiatives in the Private Housing Reconstruction in particular of disbursement of the cash grants through the Banking channel have been supported in enriching and enhancing the access to the financial services in Nepal. The government's fund transfer mechanism through the banking channel supported large number of earthquake beneficiaries residing in the rural and remote areas with limited or no formal access to financial services. The momentum of transferring funds directly to the bank account provided the BFIs great opportunities to tap the unbanked segment of the population for future customer base and retention to support in their financial requirements towards socio-economic recovery, livelihood and income generation activities. In the initial stages of the grant disbursement process in the EQ districts, in the absence of physical bank branches, the provision of providing the funds through BLB Agent was also introduced to further support the earthquake beneficiaries with on-time cash grant payment.

Overall, the access to the formal banking facilities has been found to have benefited the disaster affected victims in receiving the government's financial assistance. In the future similar enhanced grant disbursement procedure through the banks and financial institutions can be applied to provide diverse government funds including the social security funds to the targeted populace providing greater accountability, transparency, effective data management and mitigation of financial risks. It has been a great achievement of NRA's Private Housing Reconstruction initiatives in directing the cash grants to almost $99 \%$ of earthquake victims $\left(1^{\text {st }}\right.$ tranche received) through the banking channel, enhancing access to the financial services. Besides the success of disbursement of funds through the banking channel, there were some challenges reported by respondents during the study. The major challenges faced by BFIs at the time of grant disbursement process were: management of the human resource, lack financial literacy-banking related information among the beneficiaries, lack of adequate coordination among the stakeholders, merger and acquisition cases of BFIs, beneficiaries' ownership transfer, cash management, beneficiaries name mismatch, and reconciliation and data verification.

Based on this study, the following policy recommendation has been prescribed.

- To manage the public pressure in disbursing the government's financial assistance program in the disaster setting, GoN can directly credit the account of beneficiaries using Information Technology (IT). IT should be promoted to increase the efficiency of fund transfer, ensure the accountability and transparency at all levels, reduce financial and fiduciary risk as well as to dissemination about the government services and facilities. 
- Opening of the extension counters or presence of BFIs as a permanent expansion strategy is required in the remote areas for greater coverage in creating financial inclusion for the future disasters to fast track the financial assistance.

- Provide financial literacy program and other banking related procedural information to create awareness to beneficiaries and organize capacity enhancement program for involved personnel at all levels (federal-provincial-local).

- Guidelines from one entity would be better in future for instance NRB can only provide direction to the BFIs which can bring consistency in the process of grant distribution among the all-authorized BFIs.

- BFIs are recommended to manage dedicated focal team or members of the department to support such disaster-affected victims in the future to fast-track access to the financial services.

\section{REFERENCES}

Ansari, M. A., \& Mustafa, M. (2018). An analytical study of impact of merger \& acquisition on financial performance of corporate sector in India. Journal of Management Research and Analysis, 113.

Creighton, K. (2013). Introduction to Mergers \& Acquisitions. Trends.be.

Keng'ara, R. (2014). Effect of Funds Disbursement Procedures on Implementation of Donor Projects in Homabay County, Kenya. Universal Journal of Accounting and Finance, 2(1), 9-23. doi:DOI: 10.13189/ujaf.2014.020102

Modlin, S. (2014). COLLECTING AND DISBURSING: INCREASING CASH

Lamsal, R., Karki, D. T., \& Poudel, N. (2020). Importance of Socio-Technical Assistance (STA) for Vulnerable Community: Special Case of Okhaldhunga District. Rebuilding Nepal Newsletter(October-November), 24-25.

MANAGEMENT EFFICIENCY THROUGH THE UTILIZATION OF BANK SERVICES. Public Finance and Management, 14(3), 357-370.

NPC-PDNA (2015). Nepal Earthquake 2015, Post Disaster Needs Assessment (PDNA).National Planning Commission, Nepal. https://www.npc.gov.np/images/category/PDNA volume_BFinalVersion.pdf .

NRA (2020). Rebuilding Nepal (August-September). A National Reconstruction Authority Publication.

NRA (2015). Grant Disbursement Procedures for Private Houses 2015. National Reconstruction Authority. http://www.nra.gov.np/np/resources/details/ebUVxZtX4uarwnIddiIrr4Ia7SwaObKpV mXg2wpApCs

NRA-PDRA (2016). Post Disaster Recovery Framework 2016:2020.National Reconstruction Authority. Nepal.

NRA (2021). Rebuilding Nepal (April-June). A National Reconstruction Authority Publication.

NRB (2021). Third Strategic Plan 2017-21. Nepal Rastra Bank. https://www.nrb.org.np/contents/uploads/2020/01/strategic plan_2017-2021.pdf 
Odedukun, M. (2003). Analysis of Deviations and Delays in Aid Disbursements. Journal on Economic Development.

Poudel, N, Aryal, B.\& Lamsal, R. (2020). Enhancement of Access to Financial Services. National Reconstruction Authority. Available online:

http://www.nra.gov.np/np/resources/details/izJxuxWH3okrr2FG_2uE0Gz4eIZbXBPLZoiXeE v7EBQ [Accessed 21st July 2021].

Reider, R. (2008). Cash Disbursements: How to Minimize Cash Output. The Journal of Corporate Accounting \& Finance, 15-19. 